\title{
PENGATURAN TANGGUNG JAWAB KURATOR TERHADAP PENGURUSAN DAN PEMBERESAN HARTA PAILIT DALAM KAITANNYA DENGAN HAK KREDITOR SEPARATIS
}

\author{
Dewi Tuti Muryati, Dhian Septiandani, Efy Yulistyowati \\ (Dosen Fakultas Hukum Universitas Semarang)
}

\begin{abstract}
Bankrupt is a situation where the debtor is unable to make payments on his debts to one or more creditors. With the general confiscation against the bankruptcy estate, the management and settlement of property made by a debtor or a curator or Heritage Hall (BHP) under the supervision of the Supervisory Judge who appointed simultaneously by the Commercial Court at the time of the decision of a declaration of bankruptcy debtors. This is in accordance with the provisions of Article 69 paragraph (1) of Law No. 37 of 2004 which states that "the task of the curator is to perform maintenance and bankruptcy assets or settlement". The problems studied were the setting responsibilities in the management and settlement curator of the bankruptcy estate pursuant to Act No. 37 of 2004 on Bankruptcy and PKPU, and the responsibility of the curator and the obstacles encountered on the fulfillment of the rights of creditors in the administration and settlement of separatist bankruptcy assets. The method used in this research is normative juridical approach; specification research is descriptive; methods of sampling conducted with a purposive, methods of data collection using secondary data and primary data. Secondary data used include the primary legal materials, secondary law, and tertiary legal materials; then analyzed qualitatively. The survey results revealed that the setting responsibilities curator of the management and settlement of the treasure stipulated in Article 69 paragraph (1), Article 15 paragraph (3), Article 16 paragraph (1), Article 98, Article 99 of Law No. 37 of 2004, which in essence, is to carry out all efforts to secure the bankruptcy estate for the benefit of the debtor and the creditors. If the responsibility of the curator in the management and settlement bankruptcy estate associated with the rights of creditors separatists, based on Law No. 37 of 2004 on Bankruptcy and PKPU requires that efforts are made to increase the economic value of the bankruptcy estate, with the hope of the rights of all creditors especially creditors take precedence right, can be met in accordance with the amount of receivables. Curators are also required to have high integrity, professional and adhere to professional and ethical standards.
\end{abstract}

Key word: curator responsibility, secured creditor, regulation

\section{PENDAHULUAN}

Pailit merupakan suatu keadaan dimana debitor tidak mampu untuk melakukan pembayaran terhadap utang-utangnya kepada satu atau lebih kreditor. Keadaan tidak mampu membayar tersebut dikarenakan kondisi debitor yang mengalami kesulitan keuangan dari kegiatan usahanya. Lebih lanjut dalam Pasal 1 angka 1 dan Pasal 2 ayat (1) Undang-Undang Nomor 37 Tahun 2004 tentang Kepailitan dan
Penundaan Kewajiban Pembayaran Utang dinyatakan bahwa "kepailitan adalah keadaan hukum yang ditetapkan oleh Pengadilan Niaga terhadap debitor yang memiliki sedikitnya dua kreditor dan tidak mampu membayar paling sedikit satu utangnya yang telah jatuh tempo dan dapat ditagih".

Kepailitan merupakan suatu jalan keluar yang bersifat komersial untuk keluar dari persoalan utang piutang yang menghimpit 
seorang debitor, dimana debitor tersebut sudah tidak mempunyai kemampuan lagi untuk membayar utang-utang tersebut kepada para kreditornya. Apabila keadaan ketidakmampuan untuk membayar kewajiban yang telah jatuh tempo tersebut disadari oleh debitor, maka langkah untuk mengajukan permohonan penetapan status pailit terhadap dirinya (voluntary petition for self bankruptcy) menjadi suatu langkah yang memungkinkan. Apabila kemudian ditemukan bukti bahwa debitor memang telah tidak mampu lagi membayar utangnya yang telah jatuh tempo dan dapat ditagih (involuntary petition for bankruptcy), maka pengadilan dapat menetapkan status pailit terhadap debitor. ${ }^{1}$

Berdasarkan Pasal 24 ayat (1) UU No. 37 Tahun 2004 menyebutkan bahwa "terhitung sejak tanggal putusan pernyataan pailit diucapkan, maka debitor pailit demi hukum kehilangan hak untuk menguasai dan mengurusi kekayaannya yang termasuk dalam harta pailit". Dengan hilangnya hak menguasai atas kekayaannya, maka debitor tidak dapat lagi melakukan tindakan apapun terhadap hartanya, karena sebagai konsekuensi hukum terhadap pernyataan pailit adalah jatuh sita umum terhadap seluruh harta debitor baik yang ada saat pailit maupun yang diperoleh selama berada dalam kepailitan.

Dengan adanya sita umum terhadap harta pailit tersebut, maka pengurusan terhadap harta debitor dilakukan oleh seorang atau lebih kurator atau Balai Harta Peninggalan (BHP) di bawah pengawasan Hakim Pengawas yang diangkat secara bersamaan oleh Pengadilan Niaga pada saat putusan pernyataan pailit debitor. Demikian halnya dalam pemberesan harta pailit untuk menyelesaikan hutang-hutang

\footnotetext{
${ }^{1}$ Ricardo Simanjuntak, "Esensi Pembuktian Sederhana Dalam Kepailitan", dalam Emmy Yuhassarie (ed), Undang-Undang Kepailitan dan Perkembangannya, (Jakarta : Pusat Kajian Hukum, 2005), hlm. 55-56.
}

debitor terhadap kreditor atau para kreditor, akan dilakukan oleh kurator di bawah pengawasan hakim pengawas. Hal tersebut sesuai dengan rumusan Pasal 69 ayat (1) UU No 37 Tahun 2004 yang menyebutkan bahwa "tugas kurator adalah melakukan pengurusan dan atau pemberesan harta pailit". Dengan demikian dapat diketahui bahwa kurator merupakan salah satu pihak yang cukup memegang peranan dalam suatu proses perkara pailit.

Untuk mengamankan harta pailit, maka kurator dapat meminta penyegelan harta pailit kepada pengadilan melalui Hakim Pengawas, sebagaimana disebutkan dalam Pasal 99 ayat (1) UU No. 37 Tahun 2004. Penyegelan tersebut dilakukan oleh juru sita di tempat harta tersebut berada dengan dihadiri oleh 2 (dua) orang saksi yang salah satu diantaranya adalah wakil dari pemerintah daerah setempat, sebagaimana disebutkan dalam Pasal 99 ayat (2) UU No. 37 Tahun 2004.

Dalam proses pengurusan dan pemberesan harta pailit dijumpai beberapa hal berkaitan dengan daftar pembagian yang diusulkan oleh kurator kepada Hakim Pengawas, yang kemudian akan dilakukan pembayaran kepada para kreditor sesuai dengan pemeringkatan kreditor. Kedudukan para kreditor dalam kepailitan adalah sama sebagaimana yang diatur dalam Pasal 1131 KUH Perdata juncto Pasal 1132 KUH Perdata mengenai prinsip pari pasu prorate parte dan paritas creditorium, oleh karena itu mereka mempunyai hak yang sama atas hasil eksekusi harta pailit sesuai dengan besarnya tagihan mereka masing-masing. ${ }^{2}$ Kreditor dimaksud

\footnotetext{
2 Fred B.G. Tambuan, "Menelaah Konsep Dasar dan Aspek Hukum Kepailitan", Proceding Rangkaian Lokakarya Terbatas Masalah-Masalah Kepailitan dan Wawasan Hukum Bisnis Lainnya, Proceding Kepailitan dan Transfer Asset secara Melawan Hukum, (Bogor : 20 -21 Juli 2004, Pusat Pengkajian Hukum, Jakarta, 2005), hlm. 103. Lihat lebih lanjut Pasal 56 UU No. 37 Tahun 2004.
} 
meliputi baik kreditor konkuren, kreditor preferen maupun kreditor separatis.

Sehubungan dengan istilah kreditor separatis, separatis dikonotasikan pemisahan, karena kedudukan kreditor separatis memang dipisahkan dari kreditor lainnya, hal tersebut membawa pengertian bahwa kreditor separatis dapat menjual sendiri dan mengambil sendiri hasil penjualan, yang terpisah dengan harta pailit lainnya. ${ }^{3}$

Berdasarkan latar belakang yang dikemukakan tersebut maka penelitian ini bertujuan untuk : pertama, mengetahui pengaturan tanggung jawab kurator dalam pengurusan dan pemberesan harta pailit berdasarkan UU No. 37 Tahun 2004 tentang Kepailitan dan Penundaan Kewajiban Pembayaran Utang; kedua, mengetahui tanggung jawab kurator dan kendala yang dihadapi terhadap pemenuhan hak kreditor separatis dalam pengurusan dan pemberesan harta pailit.

\section{TINJAUAN PUSTAKA}

\section{Tinjauan tentang Pengaturan Kepailitan}

Secara formal hukum Kepailitan di Indonesia sudah ada sejak Tahun 1905 dengan berlakunya Stb. 1905-217 juncto Stb. 1906-348, yang kemudian telah banyak mengalami perkembangan yang diawali sejak Pemerintahan Penjajahan Belanda sampai dengan Pemerintahan Republik Indonesia. Pada Tahun 1838 pembuat Undang-Undang di Negeri Belanda menyusun Wetboek van Koophandel (Wvk) yang terdiri dari 3 bagian buku, yaitu :

1. Buku 1 tentang Van Den Koophandel in Het Algemeen yang terdiri dari $10 \mathrm{bab}$;

2. Buku II tentang Van Den Regten En Verpligtingen uit scheepvaart Voortspruitende yang pada mulanya

${ }^{3}$ Munir Fuady, Hukum Pailit dalam Teori dan Praktik, (Bandung : Rineka Cipta, 2005), hlm. 99. terdiri dari 13 bab, yang kemudian bab ke7 dihapuskan;

3. Buku III yang diberi judul Van de Voorzieningen in geval van onvermogen van Kooplieden, yang diatur dari Pasal 749 sampai dengan Pasal $910(W v k) .{ }^{4}$

Peraturan dalam Buku III Wvk tersebut hanya berlaku untuk pedagang. Di samping itu, terdapat pula Buku III Titel 8 Wetboek Van Burgelijke Rechtsvordering (BRV) yang mengatur kepailitan bukan pedagang. Dengan demikian, di Negeri Belanda pada waktu itu terjadi dualism dalam pengaturan kepailitan yaitu :

1. Kepailitan bagi pedagang diatur dalam Buku III Wvk;

2. Kepailitan bagi bukan pedagang yang diatur dalam Buku III BRV. ${ }^{5}$

Kedua buah peraturan kepailitan tersebut kemudian juga diberlakukan di Indonesia berdasarkan asas konkordansi. Oleh karena itu, sejak Tahun 1848 di Indoensia pun berlaku peraturan kepailitan yang bersifat dualistis.

\section{Tinjauan tentang Kepailitan}

Secara etimologi kepailitan berasal dari kata "pailit", yang diambil dari bahasa Belanda "faillet" yang berarti pemogokan atau kemacetan pembayaran. Dalam bahasa Inggris istilah yang digunakan adalah bankrupt (pailit) dan bankruptcy (kepailitan). ${ }^{6}$

Selanjutnya, Black's Law Dictionary mengartikan "pailit" atau "bankrupt" adalah sebagai berikut :

\footnotetext{
${ }^{4}$ Edward Manik, Cara Mudah Memahami Proses Kepailitan dan Penundaan Kewajiban Pembayaran Utang, (Bandung : Mandar Maju, 2012), hlm. 9.

5 Sastrawidjaja, Hukum Kepailitan dan Penundaan Kewajiban Pembayaran Utang, (Bandung : Alumni, 2006), hlm. 6.

6 Viktor M. Situmorang dan Hendri Soekarso, Pengantar Hukum Kepailitan Indonesia, (Jakarta : Rineka Cipta, 1993), hlm. 18.
} 
"Bankrupt is the state or condition of a person (individual, partnership, corporation, municipality) who is unable to pay its debt as they are, or become due". The term includes a person against whom a voluntary petition has been filed, or who has been adjudged a bankrupt". ${ }^{7}$

Sebelumnya kepailitan di Indonesia diatur dalam Failissements Verorderning (Peraturan Kepailitan), kemudian diubah dengan Perpu No. 1 Tahun 1998 tentang Perubahan atas UU tentang Kepailitan. Perpu ini kemudian ditetapkan sebagai undang-undang, yaitu UU No. 4 Tahun 1998 yang kemudian direvisi menjadi UU No. 37 Tahun 2004 tentang Kepailitan dan PKPU.

Adapun pengertian utang menurut Pasal 1 butir 6 UU Kepailitan dan PKPU dirumuskan sebagai berikut :

"Utang adalah kewajiban yang dinyatakan atau dapat dinyatakan dalam jumlah uang baik dalam mata uang Indonesia maupun mata uang asing, baik secara langsung maupun yang akan timbul dikemudian hari atau kontinjen, yang karena perjanjian atau undang-undang dan yang wajib dipenuhi oleh debitor dan bila tidak dipenuhi memberi hak kepada kreditor untuk mendapat pemenuhannya dari harta kekayaan debitor".

Pada prinsipnya, pengaturan masalah kepailitan merupakan suatu perwujudan atau pengejawantahan dari Pasal 1131 dan Pasal 1132 KUH Perdata, adapun rumusan dari kedua pasal tersebut adalah sebagai berikut :

\section{Pasal 1131 KUH Perdata}

"Segala kebendaan si berutang, baik yang bergerak maupun yang tak bergerak, baik yang sudah ada maupun yang baru akan ada di kemudian hari, menjadi tanggungan untuk segala perikatan perseorangan".

Pasal 1132 KUH Perdata

${ }^{7}$ Bryan A., Garner, Black Law's Dictionary, (St. Paul :West Group, 1999), hlm. 141.
"Kebendaan tersebut menjadi jaminan bersama-sama bagi semua orang yang mengutangkan padanya; pendapatan penjualan benda-benda itu dibagi-bagi menurut keseimbangan, yaitu menurut besar-kecilnya piutang masing-masing, kecuali apabila di antara para berpiutang itu ada alasan-alasan yang sah untuk didahulukan".

Dari rumusan Pasal 1131 dan Pasal 1132 KUH Perdata tersebut terkandung asasasas sebagai berikut :

a. apabila si debitor tidak membayar utangnya dengan sukarela atau tidak membayarnya, walaupun telah ada keputusan pengadilan yang menghukumnya supaya melunasi utangnya, atau karena tidak mampu untuk membayar seluruh utangnya, maka semua harta bendanya disita untuk dijual, dan hasil penjualan itu dibagi-bagikan antara semua kreditornya secara ponds-pons-gewijze, artinya menurut perimbangan, yaitu menurut besar kecilnya, piutang masing-masing kreditor, kecuali apabila diantara para kreditor itu ada alasan-alasan yang sah untuk didahulukan;

b. semua kreditor mempunyai hak yang sama;

c. tidak ada nomor urut dari para kreditor yang didasarkan atas saat timbulnya piutangpiutang mereka. $^{8}$

\section{Tinjauan tentang Kurator.}

Sejak tanggal putusan pailit, debitor pailit kehilangan haknya untuk mengurusi dan mengelola harta milik yang termasuk boedel kepailitan. Urusan tersebut harus diserahkan kepada kurator, kuratorlah yang akan melakukan pengurusan dan pemberesan harta pailit tersebut. Oleh karena itu, dalam putusan pernyataan kepailitan ditetapkan pula pihak-pihak yang ditunjuk sebagai kurator. Dulu, yang dapat menjadi kurator adalah Balai Harta Peninggalan, namun dalam perkembangannya sekarang, yang dapat menjadi kurator tidak hanya Balai Harta

\section{${ }^{8}$ Ibid}


Peninggalan, tetapi dapat pula kurator lain selain Balai Harta Peninggalan. Dalam debitor atau kreditor tidak mengajukan usul pengangkatan kurator lain kepada Pengadilan, maka Balai Harta Peninggalan bertindak sebagai kurator sebagaimana diatur dalam Pasal 15 ayat (2) UU No. 37 Tahun 2004.

Adapun pihak yang dapat menjadi kurator sebagaimana diatur dalam Pasal 70 ayat (1) dan (2) UU No. 37 Tahun 2004 adalah :

1) Orang perorangan yang berdomisili di Indonesia, yang memiliki keahlian khusus yang dibutuhkan dalam rangka mengurus dan atau membereskan harta pailit.

2) Terdaftar pada kementerian yang lingkup tugas dan tanggung jawabnya di bidang hukum dan peraturan perundangundangan.

Dengan jelas bahwa tugas kurator adalah melakukan pengurusan dan atau pemberesan harta kepailitan sebagaimana diatur dalam Pasal 69 ayat (1) UU No. 37 Tahun 2004. Tugas tersebut sudah dapat dijalankan sejak tanggal putusan pernyataan pailit dijatuhkan. Meskipun putusan tersebut belum in-kracht yakni meskipun terhadap hal tersebut masih diajukan kasasi dan atau peninjauan kembali.

Deskripsi tugas seorang kurator dalam kepailitan tersebar dalam pasal-pasal UU No. 37 Tahun 2004. Namun tugas kurator paling fundamental (sebagimana diatur dalam Pasal 67 ayat (1) UU No. 37 Tahun 2004, adalah untuk melakukan pengurusan dan pemberesan harta pailit. Dalam melakukan tugas tersebut, kurator memiliki visi utama, yaitu mengambil keputusan yang terbaik untuk memaksimalisasikan nilai harta pailit. Berhubung tugas pengurusan dan pemberesan harta pailit berada di tangan kurator, dengan sendirinya kurator mempunyai tanggung jawab penuh dalam melakukan pengurusan dan pemberesan harta pailit sebagaiman diatur dalam Pasal 74 UU No. 37 Tahun 2004. Tanggung jawab kurator atas kesalahan dan kelalaiannya dalam melaksanakan tugas pengurusan dan atau pemberesan harta pailit yang menyebabkan kerugian terhadap harta pailit diatur dalam Pasal 72 UU No. 37 Tahun 2004.

\section{Tinjauan tentang Kreditor Separatis}

Kreditor separatis adalah kreditor pemegang hak jaminan kebendaan, yang dapat bertindak sendiri, merupakan golongan kreditor yang tidak terkena akibat putusan pernyataan pailit debitor, artinya hak-hak eksekusi mereka tetap dapat dijalankan seperti tidak ada kepailitan debitor. Kreditor golongan ini dapat menjual sendiri barang-barang yang menjadi jaminan, seolah-olah tidak ada kepailitan. Namun hak ini ditangguhkan selama 90 hari (masa stay) jika debitor dinyatakan pailit oleh Pengadilan Niaga. Dalam Pasal 55 UU No. 37 Tahun 2004 dinyatakan bahwa kreditor separatis adalah kreditor pemegang gadai, jaminan fidusia, hak tanggungan, hipotik atau hak agunan atas kebendaan lainnya.

Apabila melihat makna dari kreditor separatis tersebut, dapat dikatakan undangundang memberikan kedudukan yang terpisah dari kreditor lainnya dalam mengambil pelunasan piutangnya seolah-olah tidak terjadi kepailitan atau dengan kata lain kreditor separatis dapat melakukan eksekusi secara mandiri di luar kepailitan. Walaupun kreditor separatis dapat mengeksekusi dan mengambil sendiri hasil penjualan hak jaminan, tetapi kreditor separatis tunduk pada hukum tentang penangguhan eksekusi untuk masa tertentu, yakni selama maksimum 90 hari untuk kepailitan dan maksimum 270 hari untuk penundaan kewajiban pembayaran utang.

Jadi, dalam hubungan dengan aset-aset yang dijamin tersebut kedudukan kreditor separatis sangat tinggi, lebih tinggi dari kreditor yang diistimewakan lainnya (Pasal 1139 dan 1149 KUH Perdata). Dengan perkataan lain, kedudukan kreditor separatis adalah yang tertinggi dibanding kreditor lainnya, kecuali 
undang-undang menentukan sebaliknya (Pasal 1134 ayat (2) KUH Perdata).

\section{METODE PENELITIAN}

Penelitian ini menggunakan metode pendekatan yuridis normatif. Pendekatan ini dipilih mengingat dalam rangka mencapai tujuan penelitian/ target penelitian peneliti mengacu kepada norma-norma hukum yang terdapat dalam peraturan perundang-undangan, putusanputusan pengadilan serta norma-norma hukum yang ada dalam masyarakat dan instrumen Hukum Perusahaan. Pada penelitian ini dilakukan secara deskriptif analitis, yaitu dengan memberikan gambaran secara khusus berdasarkan pada fakta yang ada. Berkaitan dengan hal tersebut, penelitian ini bermaksud memaparkan kajian normatif terhadap pengaturan tanggung jawab curator terhadap pengurusan dan pemberesan harta pailit dalam kaitannya dengan hak kreditor separator yaitu dengan mendiskripsikan dan mengintepretasikan. Dalam penelitian ini, data yang digunakan adalah data sekunder yang diperoleh dari penelitian kepustakaan yang meliputi bahan hukum primer, bahan hukum sekunder, bahan hukum tersier, Data hasil penelitian yang berupa data sekunder, dianalisis secara kualitatif.

\section{HASIL PENELITIAN DAN PEMBAHASAN} Pengaturan Tanggung Jawab Kurator Dalam Pengurusan dan Pemberesan Harta Pailit Berdasarkan Undang-Undang Nomor 37 Tahun 2004 tentang Kepailitan dan Penundaan Kewajiban Pembayaran Utang.

Tugas dan kewenangan kurator relatif berat, sebagaimana dinyatakan dalam Pasal 69 ayat (1) Undang-Undang Nomor 37 Tahun 2004 bahwa tugas kurator adalah melakukan pengurusan dan/atau pemberesan harta pailit. Lebih lanjut dinyatakan dalam Pasal 15 ayat (3) Undang-Undang Nomor 37 Tahun 2004 bahwa kurator harus independen, tidak mempunyai benturan kepentingan dengan debitor atau kreditor, dan tidak sedang menangani perkara kepailitan dan penundaan kewajiban pembayaran utang lebih dari 3 (tiga) perkara. Yang dimaksud dengan "independen dan tidak mempunyai benturan kepentingan" adalah kelangsungan keberadaan kurator tidak tergantung dari debitor atau kreditor, dan kurator tidak mempunyai kepentingan ekonomis yang sama dengan kepentingan ekonomis debitor atau kreditor. Menurut Sutan Remy Sjahdeini, bahwa dianggap telah terjadi benturan kepentingan apabila terjadi antara lain hal-hal sebagai berikut

1. Kurator menjadi salah satu kreditor;

2. Kurator memiliki hubungan kekeluargaan dengan pemegang saham pengendali atau pengurus dari perseroan debitor;

3. Kurator memiliki saham lebih dari $10 \%$ pada salah satu perusahaan kreditor atau pada perseroan debitor;

4. Kurator adalah pegawai, anggota Direksi, atau anggota Komisaris dari salah satu perusahaan kreditor atau pada perseroan debitor. $^{9}$

Pada prinsipnya kurator sudah berwenang melakukan pengurusan dan pemberesan harta pailit sejak adanya putusan pernyataan pailit dari Pengadilan Niaga, walaupun terhadap putusan tersebut diajukan upaya hukum yaitu kasasi sebagaimana ketentuan Pasal 16 ayat (1) Undang-Undang Nomor 37 Tahun 2004. Hal tersebut merupakan konsekuensi hukum dari sifat "serta merta" (uitvoorbaar bij voorraad) dari putusan pernyataan pailit sebagaimana

\footnotetext{
${ }^{9}$ Sjahdeini, Sutan Remy, Hukum Kepailitan : Memahami Faillissementsverordening Juncto Undang-Undang No. 4 Tahun 1998, (Jakarta : Pustaka Utama Grafiti, 2002), hlm. 114.
} 
ketentuan Pasal 8 ayat (7) Undang-Undang Nomor 37 Tahun 2004.

Meskipun undang-undang mengatur bahwa kurator sudah dapat menjalankan tugas dan kewenangannya setelah adanya putusan pernyataan pailit oleh Pengadilan Niaga, namun tidak berarti kurator dapat melakukan tindakan pengurusan dan pemberesan semaunya sendiri. Untuk melaksanakan tanggung jawabnya, kurator tetap harus memperhatikan hal-hal sebagai berikut :

1. Kewenangan kurator dalam melakukan tindakan tertentu;

2. Memperhatikan saat yang tepat (terutama secara ekonomi dan bisnis) untuk melakukan tindakan-tindakan tertentu, mengingat kurator harus berusaha meningkatkan nilai ekonomi dari aset debitor;

3. Perlunya izin dari pihak-pihak terkait dalam melakukan tindakan tertentu, misalnya dari Hakim Pengawas, Pengadilan Niaga, panitia kreditor, debitor, dan sebagainya;

4. Perlunya prosedur tertentu terhadap tindakan yang dilakukan oleh kurator, misalnya harus dalam rapat dengan kuorum tertentu, harus dalam sidang yang dihadiri/dipimpin oleh hakim pengawas, dan sebagainya; serta

5. Harus memperhatikan cara yang layak dari segi hukum, kebiasaan, dan sosial dalam menjalankan tindakan-tindakan tertentu, misalnya dalam melakukan penjualan aset tertentu melalui pengadilan, lelang, bawah tangan, dan sebagainya.

Setiap perbuatan kurator yang merugikan terhadap harta pailit ataupun dalam arti merugikan kepentingan kreditor, baik secara disengaja maupun tidak disengaja oleh kurator, maka kurator harus dapat mempertanggungjawabkan perbuatannya tersebut. Hal ini secara tegas dinyatakan dalam
Pasal 72 Undang-Undang Nomor 37 Tahun 2004 sebagai berikut :

"Kurator bertanggung jawab terhadap kesalahan/kelalaiannya dalam melaksanakan tugas kepengurusan dan/atau pemberesan yang menyebabkan kerugian terhadap harta pailit".

Dengan demikian kurator dalam melakukan kepengurusan dan pemberesan tidak dapat bertindak sewenang-wenang, karena apabila ada perbuatan kurator yang merugikan harta pailit, maka harta pribadi kurator ikut dipertanggungjawabkan atas perbuatan kurator tersebut. Sebagai bentuk pertanggungjawabannya, setiap 3 bulan, kurator harus menyampaikan laporan kepada hakim pengawas mengenai keadaan harta pailit dan pelaksanaan tugasnya sebagaimana disebutkan dalam Pasal 74 ayat (1) Undang-Undang Nomor 37 Tahun 2004. Laporan tersebut bersifat terbuka untuk umum dan dapat dilihat oleh setiap orang secara cuma-cuma di Pengadilan Niaga Semarang sebagaimana disebutkan dalam Pasal 74 ayat (2) Undang-Undang Nomor 37 Tahun 2004.

Kurator yang telah diangkat oleh Pengadilan Niaga Semarang sesuai dengan tanggung jawabnya yaitu melakukan pengurusan dan pemberesan atas harta pailit, dalam menjalankan tugasnya harus berdasarkan ketentuan yang telah diatur dengan jelas dan ketat pada Undang-Undang Nomor 37 Tahun 2004 yang berkaitan dengan fungsi dan tugas pokok, wewenang dan cara kerja kurator. Berdasarkan hasil wawancara dengan Panitera Pengadilan Niaga bahwa pekerjaan yang harus dilakukan oleh kurator adalah sebagai berikut :

1. Menginventarisasi harta kekayaan debitor pailit untuk kemudian menentukan mana yang masuk harta pailit, dan mana yang bukan;

2. Membuat daftar kreditor dari debitor pailit dengan menyebutkan sifat dan jumlah 
hutang debitor atau piutang kreditor beserta nama dan tempat tinggalnya;

3. Mengadakan verifikasi utang piutang kreditor dari debitor pailit dalam rapat verifikasi yang dipimpin oleh hakim pengawas;

4. Membuat daftar pembayaran piutang pada kreditor sesuai peraturan peundangundangan yang berlaku (tingkatan para kreditor).

Tanggung Jawab Kurator dan Kendala yang Dihadapi Terhadap Pemenuhan Hak Kreditor Separatis Dalam Pengurusan dan Pemberesan Harta Pailit

Berdasarkan hak kreditor pemegang hak jaminan atas kebendaan (kreditor separatis) sebagaimana dimaksud dalam Pasal 56 UndangUndang Nomor 37 Tahun 2004, yaitu penangguhan pelaksanaan hak eksekusi kreditor pemegang hak jaminan atas kebendaan (kreditor separatis) tersebut, dalam jangka waktu paling lama 90 hari terhitung mulai tanggal putusan pernyataan pailit ditetapkan, harus mendapatkan persetujuan dari kurator atau hakim pengawas. Maksud diadakannya lembaga penangguhan pelaksanaan hak kreditor separatis adalah untuk memberikan kesempatan/waktu bagi kurator untuk mengurus boedel pailit secara teratur untuk kepentingan semua pihak yang berhubungan dengan kepailitan tersebut, termasuk kemungkinan tercapainya perdamaian, atau untuk meningkatkan nilai ekonomi dari harta pailit.

Sebagai kreditor separatis, pemegang hak jaminan atas kebendaan seharusnya tidak terkena akibat putusan pernyataan pailit debitor, artinya hak-hak kreditor separatis tersebut tetap dapat dijalankan seperti tidak ada kepailitan debitor, sehingga kreditor tersebut dapat menjual sendiri barang-barang yang menjadi jaminan. Kemudian hasil penjualan tersebut diambil sebesar piutangnya, sedangkan sisanya disetorkan ke kas kurator sebagai boedel pailit. Namun apabila hasil penjualan tidak mencukupi untuk melunasi piutangnya, maka kreditor separatis dapat mendaftarkan kepada kurator pada waktu verifikasi dengan akibat berkedudukan sebagai kreditur konkuren.

Dalam pelaksanaan eksekusi terhadap benda jaminan yang dibebani Hak Tanggungan, sesuai dengan tanggung jawabnya, kurator harus berusaha semaksimal mungkin untuk memenuhi hak dari kreditor separatis. Mengingat dalam menjalankan tanggung jawabnya tersebut, kurator sering mengalami kendala pada waktu melakukan pemberesan, terutama ketika debitor tidak kooperatif selama proses pemberesan, baik secara teknis maupun non teknis. Disamping itu, kreditor separatis harus berhadapan dengan kreditor preferen yang mempunyai kedudukan istimewa yaitu diantaranya berkaitan dengan hutang pajak dan tagihan pembayaran upah pekerja.

Pada tahap pemberesan, kurator harus selalu memperhatikan nilai terbaik atas harta pailit, dengan harapan semua hak dari para kreditor dapat terbayarkan. Pemberesan dapat dilakukan sebagai satu atau lebih kesatuan usaha (going consern) atau atas masing-masing harta pailit. ${ }^{10}$ Lebih lanjut, apabila kurator dalam melakukan pemberesan dengan penjualan di muka umum atau, apabila di bawah tangan maka harus dengan persetujuan dari hakim pengawas. Walaupun kreditor separatis dapat melakukan penjualan sendiri atas barang-barang yang dijadikan jaminan, namun dimungkinkan juga penjualan barang jaminan tersebut dilakukan oleh kurator. Untuk itu demi memberikan perlindungan atas hak kreditor separatis yang mempunyai kedudukan untuk didahulukan atas pemenuhan piutangnya, maka kurator harus memperhatikan hal-hal sebagai berikut :

1. Harus menjual untuk harga yang paling tinggi;

2. Harus memutuskan apakah harta tertentu harus dijual segera dan harta yang lain

${ }^{10}$ Ibid, hlm. 238. 
harus disimpan terlebih dahulu karena nilainya akan meningkat di kemudian hari;

3. Harus kreatif dalam mendapatkan nilai tertinggi atas harta debitor pailit.

Memperhatikan Pasal Pasal 56 ayat (3) Undang-Undang Nomor 37 Tahun 2004, bahwa selama jangka waktu penangguhan, kurator dapat menggunakan harta pailit berupa benda tidak bergerak maupun benda bergerak yang berada dalam penguasaan kurator dalam rangka kelangsungan usaha debitor, dalam hal telah diberikan perlindungan yang wajar bagi kepentingan kreditor atau pihak ketiga meskipun harta tersebut dibebani hak jaminan atas kebendaan. Perlindungan tersebut berupa :

1. Ganti rugi atas terjadinya penurunan nilai harta pailit;

2. Hasil penjualan bersih;

3. Hak kebendaan pengganti; atau

4. Imbalan yang wajar dan adil serta pembayaran tunai (utang yang dijamin) lainnya.

Dengan demikian dapat diketahui bahwa barang-barang yang diikat dengan lembaga jaminan dapat dikuasai oleh kurator dan dapat dialihkan atau dijual. Sekalipun ada perlindungan bagi kreditor separatis sehubungan dengan tindakan kurator untuk menggunakan benda-benda jaminan kebendaan tersebut, namun pada kenyataannya pengaturan ini telah menghilangkan hak eksekusi dari kreditor separatis. ${ }^{11}$ Dalam hal penjualan barang-barang yang dibebani hak jaminan atas kebendaan tersebut dilakukan oleh kurator, maka hasil penjualan tersebut akan dikurangi dengan biaya kurator. Pengurangan tersebut tidak akan berpengaruh terhadap jumlah hak yang harus diperoleh kreditor separatis, manakala hasil

11 Sularso, "Perlindungan Hukum Kreditor Separatis dalam Kepailitan”, Bagian Hukum Perdata, Fakultas Hukum Universitas Gadjah Mada, Yogyakarta, Mimbar Hukum, Volume 24 No. 2 Juni 2012, hlm. 249-250. penjualan tersebut memenuhi piutangnya, namun apabila hasil penjualan tidak menutupi piutangnya maka pengurangan biaya kurator akan mengurangi hak kreditor separatis. dengan tetap memperhatikan tanggung jawab kurator atas kepentingan kreditor separatis, perlu juga dicermati mengenai kompetensi dan kemampuan kurator dalam mengurus dan melakukan pemberesan harta pailit. Mengingat tidak profesionalnya kurator dalam mengurus harta debitor yang telah dinyatakan pailit merupakan salah satu faktor yang menghambat proses pemberesan.

Untuk menghindari adanya benturan kepentingan antara kurator dengan kreditor separatis dan agar hak kreditor separatis tetap terpenuhi sesuai dengan besarnya piutang tanpa merugikan kreditor lainnya, maka kurator dituntut untuk memiliki integritas yang berpedoman pada kebenaran dan keadilan serta keharusan untuk mentaati standar profesi dan etika dengan tetap berdasarkan kepada peraturan perundang-undangan terkait. Disamping itu, kurator juga dituntut lebih profesional dalam mengurus harta debitor yang telah dinyatakan pailit. Kurator profesional yang dimaksud dalam hal ini adalah kurator yang mempunyai kemampuan penguasaan bidang hukum dan juga memiliki kemampuan dalam pengelolaan suatu usaha khususnya yang berkaitan dengan audit pembukuan.

\section{PENUTUP \\ Simpulan}

Pengaturan tanggung jawab kurator dalam pengurusan dan pemberesan harta pailit berdasarkan Undang-Undang Nomor 37 Tahun 2004 tentang Kepailitan dan Penundaan Kewajiban Pembayaran Utang dapat diketahui bahwa tugas dan kewenangan kurator relatif berat, sebagaimana ketentuan dalam Pasal 36 ayat (1) Undang-Undang Nomor 37 Tahun 2004 yang menyatakan bahwa tugas kurator adalah melakukan pengurusan dan/atau pemberesan 
harta pailit. Lebih lanjut dinyatakan dalam Pasal 15 ayat (3) Undang-Undang Nomor 37 Tahun 2004 bahwa kurator harus independen, tidak mempunyai benturan kepentingan dengan debitor atau kreditor, dan tidak sedang menangani perkara kepailitan lebih dari 3 (tiga) perkara. Meskipun undang-undang mengatur bahwa kurator sudah dapat menjalankan tugas dan kewenangannya setelah adanya putusan pernyataan pailit oleh Pengadilan Niaga, namun tidak berarti kurator dapat melakukan tindakan pengurusan dan pemberesan semaunya sendiri.

Tanggung jawab kurator dan kendala yang dihadapi terhadap pemenuhan hak kreditor separatis dalam pengurusan dan pemberesan harta pailit, dapat diketahui bahwa dalam pelaksanaan eksekusi terhadap benda jaminan yang dibebani hak tanggungan, kurator harus harus berusaha semaksimal mungkin untuk memenuhi hak dari kreditor separatis. Mengingat dalam menjalankan tanggung jawabnya tersebut, kurator sering mengalami kendala pada waktu melakukan pemberesan, terutama ketika debitor tidak kooperatif selama proses pemberesan, baik secara teknis maupun non teknis. Disamping itu, kreditor separatis harus berhadapan dengan kreditor preferen yang mempunyai kedudukan istimewa yaitu diantaranya berkaitan dengan hutang pajak dan tagihan pembayaran upah pekerja. Pada tahap pemberesan, kurator harus selalu memperhatikan nilai terbaik atas harta pailit, dengan harapan semua hak dari para kreditor dapat terbayarkan. Walaupun kreditor separatis dapat melakukan penjualan sendiri atas barang-barang yang dijadikan jaminan, namun dimungkinkan juga penjualan barang jaminan tersebut dilakukan oleh kurator. Untuk menghindari adanya benturan kepentingan antara kurator dengan kreditor separatis dan agar hak kreditor separatis tetap terpenuhi sesuai dengan besarnya piutang tanpa merugikan kreditor lainnya, maka kurator dituntut untuk memiliki integritas yang berpedoman pada kebenaran dan keadilan serta keharusan untuk mentaati standar profesi dan etika dengan tetap berdasarkan kepada peraturan perundang-undangan terkait. Disamping itu, kurator juga dituntut lebih profesional dalam mengurus harta debitor yang telah dinyatakan pailit. Kurator profesional yang dimaksud dalam hal ini adalah kurator yang mempunyai kemampuan penguasaan bidang hukum dan juga memiliki kemampuan dalam pengelolaan suatu usaha khususnya yang berkaitan dengan audit pembukuan.

\section{Saran}

Mempertegas pengaturan tanggung jawab kurator dalam pengurusan dan pemberesan harta debitor pailit, terutama dalam mengelompokkan harta milik debitor pailit yang masuk dalam harta pailit dan yang tidak masuk dalam harta pailit.

Pemerintah harus melakukan harmonisasi terhadap peraturan perundangundangan yang berkaitan dengan pengaturan Kepailitan dan Penundaan Kewajiban Pembayaran Utang dengan pengaturan tentang Hukum Jaminan, yang menekankan kepada berlakunya hukum jaminan secara benar dalam undang-undang kepailitan.

Dalam menjalankan tanggung jawabnya, kurator harus profesional, memiliki integritas, menaati standar profesi dan etika, sehingga dapat memberikan perlindungan hukum kepada krditor separatis dalam memperoleh hak-haknya sebagaimana diamanatkan oleh undang-undang.

\section{DAFTAR PUSTAKA BUKU}

Bryan A., Garner. 1999. Black Law's Dictionary. St. Paul : West Group.

Edward Manik. 2012. Cara Mudah Memahami Proses Kepailitan dan Penundaan Kewajiban Pembayaran Utang. Bandung : Mandar Maju.

Fred B.G. Tambuan. 2005. Jakarta : Pusat Kajian Hukum. "Menelaah Konsep Dasar dan Aspek Hukum Kepailitan”, Proceding Rangkaian Lokakarya Terbatas Masalah- 
Masalah Kepailitan dan Wawasan Hukum Bisnis Lainnya, Proceding Kepailitan dan Transfer Asset secara Melawan Hukum, (Bogor : 20 -21 Juli 2004).Munir Fuady. 2005. Hukum Pailit dalam Teori dan Praktik. Bandung : Rineka Cipta.

----------- . 2014. Hukum Pailit dalam Teori dan Praktik. Bandung : Rineka Cipta.

Ricardo Simanjuntak. 2010. "Esensi Pembuktian Sederhana Dalam Kepailitan", dalam Emmy Yuhassarie (ed), Undang-Undang Kepailitan dan Perkembangannya. Jakarta : Pusat Kajian Hukum.

Sastrawidjaja. 2006. Hukum Kepailitan dan Penundaan Kewajiban Pembayaran Utang. Bandung : Alumni.

Sjahdeini, Sutan Remy. 2002. Hukum Kepailitan : Memahami Faillissementsverordening Juncto Undang-Undang No. 4 Tahun 1998. Jakarta : Pustaka Utama Grafiti.

Sularso. 2012. "Perlindungan Hukum Kreditor Separatis Dalam Kepailitan". Yogyakarta : Mimbar Hukum.

Viktor M. Situmorang dan Hendri Soekarso. 1993.Pengantar Hukum Kepailitan Indonesia. Jakarta : Rineka Cipta.

\section{PERATURAN PERUNDANG-UNDANGAN}

KUH Perdata

UU No. 9 Tahun 1994 tentang Perpajakan

UU No. 13 Tahun 2003 tentang Ketenagakerjaan

UU No. 37 Tahun 2004 tentang Kepailitan dan Penundaan Kewajiban Pembayaran Utang

UU No. 40 Tahun 2007 tentang Perseroan Terbatas

UU No. 4 Tahun 2009 tentang Hak Tanggungan atas Tanah beserta Benda-benda yang Berkaitan dengan Tanah 